Volume 3 Issue 1 (2019) Pages 68 - 81

Jurnal Obsesi : Jurnal Pendidikan Anak Usia Dini

DOI: $10.31004 /$ obsesi.v3i1.135

\title{
Upaya Meningkatkan Keterampilan Mengajar Baca Tulis Al-Qur`An bagi Guru
}

\author{
Nadri Taja $^{1 \bowtie,}$ Dinar Nur Inten ${ }^{2}$, Arif Hakim ${ }^{3}$ \\ Universitas Islam Bandung, Jawa Barat
}

\begin{abstract}
This study aims to determine the improvement of teacher teaching skills madrasah diniyyah takmiliyyah through listening, playing and storytelling techniques abbreviated as MATA techniques. The research was conducted in October using Participatory Rural Appraisal (PRA) method with a quantitative analysis model. The subjects of this study were madrasa teachers who were in 18 diniyyah takmiliyyah located in the Bandung regency region precisely in the Pangalengan sub-district of Lamajang village. The results of the study showed an increase in teacher understanding after using the MATA technique, which increased by an average of $78.9 \%$, an increase of $23.3 \%$ from the initial ability on average at $49 \%$. As for the constraints faced, for example teachers find it difficult to condition their children to stay focused, look for strategies so that children remain enthusiastic and enthusiastic in participating in the lesson, and mastery and application of MATA techniques is still not optimal. While the positive impact of the application of MATA techniques increases the activeness and creativity of teachers and is able to involve all students in learning. The advice recommended in this study is that other trainings should be held for teachers, then given examples of more learning practices in the form of books and training CDs so that they can be expanded again.
\end{abstract}

Keywords: Al-Qur'an Study, Listen, Play, and Tell Stories

\section{Abstrak}

Penelitian ini bertujuan untuk mengetahui peningkatan keterampilan mengajar guru madrasah diniyyah takmiliyyah melalui teknik menyimak, bermain, dan bercerita yang disingkat dengan teknik MATA. Penelitian dilaksanankan pada bulan oktober dengan menggunakan metode Participatory Rural Appraisal (PRA) dengan model analisis kuantitatif. Subjek penelitian ini adalah guru madrasah yang berada di 18 diniyyah takmiliyyah yang berlokasi di wilayah kabupaten Bandung tepatnya di kecamatan Pangalengan desa Lamajang. Hasil penelitian menunjukkan adanya peningkatan pemahaman guru setelah menggunakan teknik MATA, yakni meningkat rata-rata sampai pada angka $78,9 \%$, mengalami peningkatan sejumlah $23,3 \%$ dari kemampuan awal rata-rata berada pada $49 \%$. Adapun kendala yang dihadapi, misalnya guru sulit mengkondisikan anak untuk tetap fokus, mencari strategi agar anak tetap semangat dan antusias dalam mengikuti pelajaran, dan penguasaan dan penerapan teknik MATA masih belum maksimal. Sedangkan dampak positif penerapan teknik MATA ini meningkatkan keaktifan dan kreatifitas guru dan mampu melibatkan seluruh siswa dalam pembelajaran. Adapun saran yang direkomendasikan dalam penelitian ini adalah hendaknya diadakan pelatihan-pelatihan lainnya bagi guru, kemudian diberikan contoh-contoh praktek pembelajaran yang lebih banyak dalam bentuk buku dan CD pelatihan agar diperluas kembali jangkauannya.

Kata Kunci: Baca Tulis Al-Qur`an, Menyimak, Bermain, dan Bercerita

@Jurnal Obsesi Prodi PG-PAUD FIP UPTT 2019

$\triangle$ Corresponding author:

Address : Jalan.Ranggagading No.8, Bandung

ISSN 2356-1327 (Media Cetak)

Email : nadritaja@gmail.com ISSN 2549-8959 (Media Online) 


\section{PENDAHULUAN}

Usia dini merupakan fase pembentukan kepribadian yang tepat untuk ditanamkan nilai-nilai kebaikan ke dalam jiwa setiap anak. Sosok guru memiliki peran sentral dalam membimbing, mendidik, dan mengerahkan segenap potensi yang dimiliki peserta. Dengan asumsi bahwa fase ini sering disebut sebagai periode keemasan (golden age) dan memiliki kemampuan menerima rangsangan dari luar lebih cepat, sehingga perlu diarahkan kepada hal-hal yang bersifat positif (Muhadi, 2016). Wajar apabila kita membaca sejarah bahwa Imam Syafii telah hafal al-Qur`an pada usia 7 tahun, hafal kitab Al-Muwaththa' Imam Malik pada usia 9 tahun, dan pada usia 10 tahun telah menguasai tafsir al-Qur`an (Adhim, 2013). Kemampuan hafalan dan pemahaman terhadap al-Qur`an yang masih tergolong langka di usianya yang cenderung kebanyakan anak-anak lebih senang bermain daripada menghabiskan waktunya untuk belajar.

Hal di atas sangat relevan bila dikaitkan dengan sebuah hasil riset yang dilakukan oleh Gardner (Cahyaningrum, Sudaryanti, \& Nurtanio, 2017) menunjukkan bahwa perkembangan otak manusia mengalami lompatan dan berkembang sangat pesat, yaitu mencapai $80 \%$. Ketika dilahirkan ke dunia seorang anak telah mencapai perkembangan otak $25 \%$, sampai usia 4 tahun perkembangannya mencapai $50 \%$, dan sampai 8 tahun mencapai $80 \%$, selebihnya berkembang sampai usia 18 tahun. Oleh karenanya, mendidik anak pada fase usia dini menjadi kebutuhan yang paling fundamental dan kelak menjadi bekal untuk mengisi jiwa mereka senantiasa hidup di bawah naungan al-Qur'an ( $f i$ dhilālil qur`an)
Atas dasar itu pula pelaksanaan pembelajaran al-Qur’an sangat diperlukan untuk dilakukan sejak dini sebagai bentuk habituasi nilai-nilai kebaikan, yakni untuk memaksimalkan kemampuan kognitif, psikomotorik dan afektif yang termasuk ke dalam dimensi tujuan pembelajaran dan dinamika pembelajaran yang bersifat internal. Sedangkan dinamisasi dari luar (eksternal) berasal dari guru atau pendidik, dimana pendinamisasian belajar tersebut berkenaan dengan kesiapan anak didik menghadapi bahan ajar, penciptaan suasana belajar yang menyenangkan, optimalisasi media, sumber belajar, dan mengoptimalkan peran sebagai pembelajar. Dua aspek penting dalam kegiatan pembelajaran, yakni aspek pertama berkaitan dengan aspek hasil belajar yang berupa perubahan tingkah laku, dan aspek kedua berkaitan dengan aspek proses belajar yang berupa sejumlah pengalaman intelektual, emosional, dan fisik pada diri anak didik (Hadi, 2017)

Faktor keberhasilan pendidikan ditunjang oleh kompetensi guru dalam layanan pembelajaran yang menunjukkan profesionalitas di dalam kepribadiannya. Tugas yang digambarkan itu adalah 1) penyelenggaraan proses pembelajaran yang menuntut guru untuk menguasai materi dan mengemasnya sesuai scope, sequence, dan tujuan pendidikan, 2) tugas yang berhubungan dengan murid dalam mengatasi masalah belajar, 3) guru harus memahami bagaimana kegiatan pembelajaran di sekolah itu dikelola (Rusman, 2013). Atas dasar inilah, seorang guru dituntut lebih kreatif serta inovatif dalam mengemas kegiatan pembelajaran agar mampu memberikan pemahaman yang utuh dan dapat dipahami oleh siswa dengan baik.

Terdapat 18 diniyah binaan yang dijadikan subjek pengabdian yaitu Diniyyah Takmiliyyah (DT) Al- 
70 | Upaya Meningkatkan Keterampilan Mengajar Baca Tulis Al-Qur`An bagi Guru

Muqoddasah, DT Baitul Jannah, DT Balai Iqro; DT Al-Islamiyah, DT Al-Huda, DT Al-Istiqomah, DT Al-Hikmah, DT Nurul Iman, DT Al-Ikhlas, DT At-Tana'im, DT Al-Hidayah, DT Al-Jihad, DT AlMujahidin, DT Assalam, DT Mekarsari, DT Al-Muhajirin, DT Al-Barokah, dan DT Al-Hudayah di wilayah kabupaten Bandung tepatnya di desa Lamajang yang sudah lama menjalankan kegiatan pembelajaran al-Qur`an dengan karakteristik yang beragam, dimana peneliti merasa tertarik untuk mengamati lebih jauh. Pemilihan dampingan didasarkan kepada: 1) Sejak pertamakali dibentuknya Forum Komunikasi Diniyyah Takmiliyyah (FKDT) di Kecamatan Pangalengan, para guru belum pernah mendapatkan sekalipun pendidikan dan pelatihan keterampilan bagi guru, guna meningkatkan kompetensi para Guru Diniyyah Takmiliyyah, 2) Latar belakang Pendidikan Guru Diniyyah Takmiliyyah yang sebagian besar masih belum relevan dengan profesionalitas, mengingat idealnya bagi seorang guru Diniyyah Takmiliyyah haruslah lulusan yang memiliki linearitas dengan bidang Pendidikan Agama Islam, 3) Kondisi di lapangan menunjukkan tingkat keterampilan anak di dalam membaca dengan tartīl kemudian diiringi pemahaman tentang kandungan al-Qur`an secara sederhana, masih jauh dari target capaian. Anak usia 10-11 tahun masih ditemukan banyak yang belum bisa membaca bacaan dengan tartīl.

Melalui kegiatan menyimak, bermain, dan bercerita menjadi salah satu alternatif diantara teknik mengajar alQur`an yang ditawarkan oleh penulis dan solusi untuk menangani permasalahan yang terjadi di atas, disamping terdapat beragam metode mengajar al-Qur`an lainnya seperti metode ummi, metode Baghdad, metode iqro, dan metode anNahdiyah yang tentunya memiliki karakterstik tersendiri yang khas dari setiap metode. Akan tetapi pada intinya memiliki satu tujuan sama yakni memberikan pemahaman yang baik terhadap cara membaca al-Qur`an dan mampu mempraktikan bacaan al-Qur`an sesuai dengan kaidah tajwid. Kegiatan menyimak menurut Sabarti (Dhieni, et.al., 2008) merupakan suatu proses yang mencakup kegiatan mendengarkan bunyi bahasa, mengidentifikasi, menginterpretasi nilai, dan mereaksi atas makna yang terkandung di dalamnya. Dalam hal ini seputar materi tajwid untuk membaca alQur`an yang dijadikan fokus penelitian.

Sedangkan permainan merupakan sarana aktivitas fisik dan nalar yang dapat memberikan kenikmatan dan kebahagiaan bagi seorang anak, yang dilakukan secara kelompok dapat memberikan dampak pada anak, berupa perilaku positif, kemampuan dan pemahamahan yang baru (Musthafa, 2004). Pada aspek bermain, seorang guru hendaknya menggunakan instrument atau alat peraga sebagai bentuk kegiatan pembelajaran yang menyenangkan agar pembelajaran dirasa tidak menjemukan dan untuk melatih motorik kasar peserta didik agar. Pada kegiatan bercerita merupakan tuturan yang membentangkan bagaimana terjadinya suatu hal, peristiwa, kejadian atau lakon yang diwujudkan atau dipertunjukkan dan digambar hidup seperti sandiwara dan wayang (Musfiroh, 2005). Muatan materi cerita yang diberikan tentang kisah atau dongeng yang menjelaskan tentang kandungan ayat yang bermuatan nilai-nilai pendidikan serta memiliki relevansi ajaran moral yang menyentuh perasaan.

Teknik mengajar yang terdiri dari menyimak, bercerita, dan bermain yang disingkat dengan MATA muncul dari fenomena tentang kemampuan membaca al-Qur’an yang tergolong rendah serta terlalu monotonnya teknik mengajar yang 
digunakan guru sehingga mengakibatkan kegiatan pembelajaran menjemukan dan kurang bermakna, siswa menjadi malas belajar dan cenderung pasif. Inti dari adanya teknik MATA ini sebenarnya untuk meningkatkan kemampuan membaca alQur`an agar pendidikan memiliki alternatif teknik mengajar yang lebih bermakna dan akhirnya siswa terhindar dari membaca alQur'an dengan "apal cangkem” (hafal dimulut tetapi tidak memahaminya dan tidak mampu mengaplikasikannya).

Sedemikian vitalnya pendidikan alQur`an untuk anak usia dini megingat tahap yang paling fundamental bagi perkembangan individu anak. Tidak semata-mata hanya untuk formalitas dalam menyelesaikan tahapan belajar, melainkan kualitas mereka di kemudian hari kelak dalam membaca sesuai kaidah tajwid, memahami makna al-Qur`an, dan menginternalisasikan nilai-nilai al-Quran ke dalam jiwanya. Karena pada hakikatnya seorang anak dibekali potensi bawaan (Q.S. An-Nahl (16): 78), yaitu potensi indrawi (psikomotrik), IQ, Emotional Question, dan Spiritual Quesiont dengan tujuan untuk mengaktualisasikannya menjadi kompetensi (Madyawati, 2016). Dengan kata lain teknik MATA menjadi gerakan dalam memberantas buta huruf baca al-Qur'an. Dalam segi tahapan pembelajaran agar bisa membaca dengan benar bersesuaian dengan teori Cochrane Efal (Kurniawan, Khomsiyatun, \& Samiaji, 2018) tentang tahapan perkembangan membaca, yakni pertama, magical stage atau tahap fantasi. Tahap ini anak menjadikan buku iqro atau al-Qur`an yang dilengkapi dengan animasi/ilustrasi sebagai media yang menyenangkan. Kedua, self concept stage atau tahap pembentukan konsep diri. Anak mulai terlibat dalam kegiatan membaca buku dan memahami gambar berdasarkan pengalaman yang diperoleh. Ketiga, bridging reading stage atau tahap membaca gambar. Tahap ini anak mulai tumbuh kesadaran untuk menemukan huruf hijaiyyah atau huruf sambung melalui ilustrasi gambar yang kemudian disusun gambar tersebut menjadi cerita yang menyenangkan dan dipahami oleh anak. Keempat, take off reader stage atau tahap mengenal bacaan. Tahap ini anak mulai tertarik pada bacaan, mengenal huruf yang bertanda harakat. Disini guru menggunakan mendampinginya dengan kegiatan bermain dan bercerita sehingga membangkitkan penasaran dan tertarik untuk senantiasa membaca. Dan kelima, independent reader stage atau tahap lancar membaca. Pada tahap ini anak sudah dapat membaca tulisan dengan lancar tanpa ada dampingan dari orang terdekat.

\section{METODOLOGI}

Penelitian ini menggunakan Participatory Rural Appraisal (PRA) atau Pemahaman Partisipatif Kondisi Pedesaan. PRA merupakan pendekatan dan metode yang melibatkan seluruh komponen masyarakat secara bersama-sama untuk menganalisis masalah kehidupan dalam rangka merumuskan perencanaan dan kebijakan secara nyata dan tindakan nyata (Chambers, 1996). Dengan teknik pengumpulan data berupa observasi, wawancara mendalam, pre test dan post test dalam bentuk angket untuk mengetahui kemampuan mengajar sebelum dan sesudah mengikuti pelatihan MATA. Analisis data dalam penelitian ini dilakukan dengan model kuantitatif.

Subjek penelitian ini berlokasi di desa Lamajang kecamatan Pangalengan Kabupaten Bandung yang terdiri dari 18 diniyyah takmiliyyah yakni Diniyyah Takmiliyyah (DT) Al-Muqoddasah, DT Baitul Jannah, DT Balai Iqro; DT AlIslamiyah, DT Al-Huda, DT Al-Istiqomah, DT Al-Hikmah, DT Nurul Iman, DT Al- 
72 | Upaya Meningkatkan Keterampilan Mengajar Baca Tulis Al-Qur`An bagi Guru

Ikhlas, DT At-Tana'im, DT Al-Hidayah, DT Al-Jihad, DT Al-Mujahidin, DT AsSalam, DT Mekarsari, DT Al-Muhajirin, DT Al-Barokah, dan DT Al-Hudayah. Dipilihnya diniyyah takmiliyyah tersebut karena para guru disana telah memiliki pengetahuan, pemahaman dan pengalaman yang mumpuni sehingga dapat diterapkan sesuai dengan materi yang diajarkan dalam pelatihan MATA.

\section{HASIL DAN PEMBAHASAN}

Kegiatan Pelatihan teknik MATA dilaksanakan selama tiga minggu berturutturut setiap hari senin, tanggal 15, 22, dan 29 Oktober 2018. Tujuan dilakukan dari kegiatan pelatihan ini adalah sebagai upaya memberikan pemahaman dan pendalaman materi yang disampaikan kepada para guru agar kualitas pembelajaran meningkat dengan baik. Antusias guru sangatlah besar, tampak dari tingkat kehadiran di setiap pertemuan mencapai $97 \%$. Kegiatan pelatihan teknik MATA bagi guru diniyyah takmiliyyah bertempat di Madrasah AlMuqodasah Jalan Raya BanjaranPangalengan.

Rangkaian kegiatan selama tiga pekan berturut-turut diawali pembuka kegiatan dengan melakukan pre test seputar teknik MATA. Misalnya, pada tanggal 15 Oktober 2018 materi yang diberikan adalah teknik menyimak, maka soal pre test yang diberikan khusus terkait pemahaman awal guru tentang menyimak. Tanggal 22 Oktober 2018 materi yang disampaikan adalah tentang teknik bermain, dan dilakukan pre test tentang konsep bermain. Puncak tahap pelaksanaan kegiatan pada tanggal 29 Oktober 2018, materi yang disampaikan adalah bercerita, maka soal pre test nya pun tentang bermain.

Pasca pre test dilakukan maka masuk kepada kegiatan inti yakni pemaparan materi teknik MATA. Dengan pemetaan substansi kegiatan sebagai berikut:

\section{Tabel 1. Pemetaan Materi dan Tujuan Teknik Menyimak, Bermain, dan}

Bercerita

\begin{tabular}{|c|c|c|}
\hline Pembicara & Materi & Tujuan \\
\hline $\begin{array}{l}\text { Nadri } \\
\text { Taja, } \\
\text { S.Pd., } \\
\text { M.Pd. }\end{array}$ & $\begin{array}{l}\text { a. Tujuan kegiatan } \\
\text { penelitian } \\
\text { berbasis } \\
\text { pengabdian; } \\
\text { b. Pengertian } \\
\text { menyimak; } \\
\text { c. Tahapan } \\
\text { menyimak } \\
\text { melalui teknik } \\
\text { MATA; } \\
\text { d. Simulasi } \\
\text { menyimak } \\
\text { melalui teknik } \\
\text { MATA. }\end{array}$ & 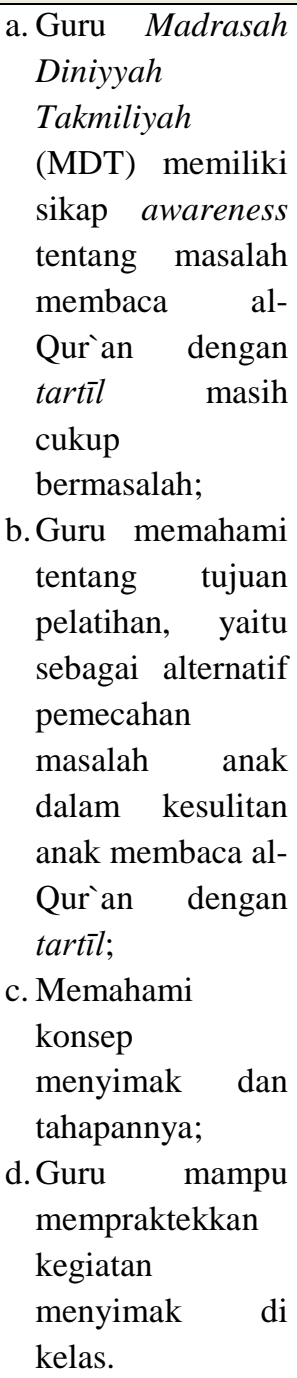 \\
\hline $\begin{array}{l}\text { Arif } \\
\text { Hakim, } \\
\text { M.Pd. }\end{array}$ & $\begin{array}{l}\text { a. Pengertian } \\
\text { bermain; } \\
\text { b. Manfaat } \\
\text { bermain bagi } \\
\text { anak; } \\
\text { c. Praktik bermain } \\
\text { mengenalkan } \\
\text { huruf hijaiyah } \\
\text { untuk } \\
\text { madrasah } \\
\text { diniyyah kelas } \\
\text { 1-2 MD; } \\
\text { d. Pengembangan } \\
\text { bermain } \\
\text { mengenalkan } \\
\text { huruf hijaiyah } \\
\text { dengan }\end{array}$ & $\begin{array}{l}\text { a. Guru memahami } \\
\text { tujuan bermain } \\
\text { sebagai bagian } \\
\text { dari upaya } \\
\text { alternatif metode } \\
\text { bagi } \\
\text { pembelajaran di } \\
\text { kelas MD; } \\
\text { b. Guru } \\
\text { mengetahui } \\
\text { contoh macam- } \\
\text { macam } \\
\text { permainan dalam } \\
\text { pembelajaran di } \\
\text { MD; } \\
\text { c. Guru } \\
\text { mempraktekkan }\end{array}$ \\
\hline
\end{tabular}




\begin{tabular}{|c|c|c|}
\hline Pembicara & Materi & Tujuan \\
\hline & $\begin{array}{l}\text { melibatkan para } \\
\text { peserta guru } \\
\text { MD; } \\
\text { e. Simulasi } \\
\text { bermain. }\end{array}$ & 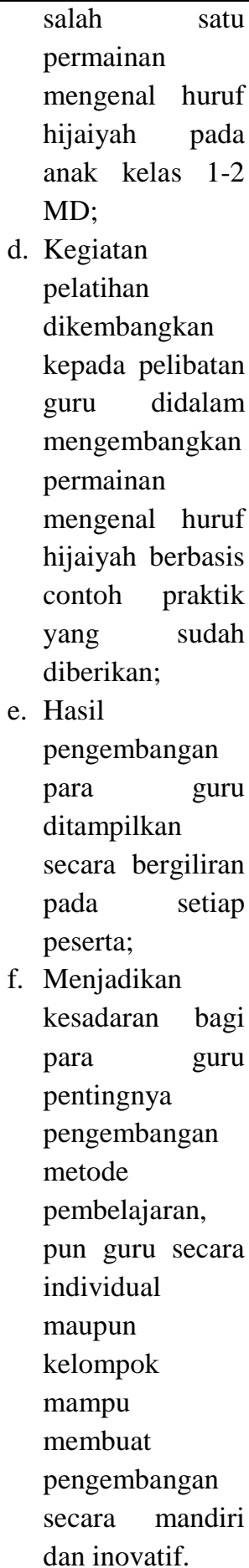 \\
\hline $\begin{array}{l}\text { Dinar Nur } \\
\text { Inten, } \\
\text { S.Pd., } \\
\text { M.Pd }\end{array}$ & $\begin{array}{l}\text { a. Pengertian } \\
\text { bercerita; } \\
\text { b. Materi } \\
\text { bercerita; } \\
\text { c. Tahapan } \\
\text { bercerita; } \\
\text { d. Praktek } \\
\text { bercerita. }\end{array}$ & $\begin{array}{l}\text { a. Guru memahami } \\
\text { hubungan antara } \\
\text { menyimak dan } \\
\text { bercerita diikat } \\
\text { oleh kegiatan } \\
\text { bermain dalam } \\
\text { belajar al- } \\
\text { Qur`an; } \\
\text { b. Guru } \\
\text { mengetahui } \\
\text { materi-materi } \\
\text { cerita yang dapat } \\
\text { diadopsi dari al- }\end{array}$ \\
\hline
\end{tabular}

\begin{tabular}{|c|c|c|}
\hline Pembicara & Materi & Tujuan \\
\hline & & $\begin{array}{l}\text { Qur`an; } \\
\text { c. Guru } \\
\text { mengetahui } \\
\text { bagaimana } \\
\text { tahapan didalam } \\
\text { menyampaikan } \\
\text { cerita agar } \\
\text { memiliki } \\
\text { kebermaknaan } \\
\text { tentang isi al- } \\
\text { Qur`an; } \\
\text { d. Guru belajar } \\
\text { cara } \\
\text { mempraktekkan } \\
\text { bercerita di kelas } \\
\text { dengan simulasi. }\end{array}$ \\
\hline
\end{tabular}

Secara garis besar, tujuan dari tiga rangkaian teknik ini memiliki irisan dengan teori Taksonomi Bloom dimana teknik menyimak sebagai upaya pencapaian pemahaman konsep (kognitif), teknik bermain untuk melatih motorik kasar (psikomotorik), dan teknik bercerita sebagai upaya internalisasi nilai-nilai positif yang menyentuh jiwa sehingga mampu menggugah kesadaran untuk berperilaku baik sesuai dengan materi yang dikaji (afektif). Penjabaran ketiga teknik MATA ini dapat dipahami sebagai berikut:

Pertama, pada kegiatan menyimak agar dapat sampai pada pemahaman yang komprehensif maka terdapat serangkaian tahapan yang perlu dilakukan, diantaranya: 1) Menyimak berkala, yang terjadi pada saat-saat anak merasakan keterlibatan langsung dalam pembicaraan mengenai dirinya; 2) Menyimak dengan perhatian dangkal, karena sering mendapat gangguan dengan adanya selingan-selingan perhatian kepada hal-hal di luar pembicaraan; 3) Setengah menyimak karena terganggu oleh kegiatan menunggu kesempatan untuk mengekspresikan isi hati serta mengutarakan apa yang terpendam dalam hati sang anak; 4) Menyimak serapan karena sang anak keasyikan menyerap atau mengabsorpsi hal-hal yang kurang penting, 
hal ini merupakan penjaringan pasif yang sesungguhnya; 5) Menyimak sekali-sekali, menyimpan sebentar-sebentar apa yang disimak; perhatian secara seksama berganti dengan keasyikan lain; hanya memperhatikan kata-kata sang pembicara yang menarik hatinya saja; 6) Menyimak asosiatif, hanya mengingat pengalamanpengalaman pribadi secara konstan yang mengakibatkan sang penyimak benarbenar tidak memberikan reaksi terhadap pesan yang disampaikan sang pembicara; 7) Menyimak dengan reaksi berkala terhadap pembicara dengan membuat komentar ataupun mengajukan pertanyaan; 8) Menyimak secara saksama, dengan sungguh-sungguh mengikuti jalan pikiran sang pembicara; 9) Menyimak secara aktif untuk mendapatkan serta menemukan pikiran, pendapat, dan gagasan sang pembicara (Strickland dalam Dhieni, 2008). Manfaat dari kegiatan menyimak adalah terlibatnya panca indera untuk terlatih memahami susunan kata, pelafalan kalimat, dan intonasi dengan benar.

Implementasi dalam materi alQur`an, misalnya tentang hukum bacaan tajwìd nun mati dan tanwin dengan langkah-langkah sebagai berikut:

Pokok Materi; Diawali dengan penjelasan materi tentang kedudukan nun mati dan tanwin, seperti idzhar, idgham, $i k h f a$, dan iqlab. Siswa diminta untuk menyimak materi dengan seksama; kemudian Guru membacakan contoh ayat dalam al-Qur`an dari nun mati dan tanwin, kemudian diikuti oleh siswa untuk membacakannya. Selanjutnya memberikan kesempatan pada siswa apabila terdapat pertanyaan seputar materi;selanjutnya setelah siswa mempraktikannya, guru kemudian memilih salah satu ayat dalam al-Qur`an, yaitu surat at-Takwir sebagai bentuk latihan dan pemahaman tentang materi hukum nun mati dan tanwin; pada tahap berikutnya Guru menyimak setiap bacaan dari setiap siswanya, untuk kemudian dievaluasi baik dari pelafalan setiap hurufnya maupun pelafalan hukum tajwid nun mati dan tanwin; pada akhir pembelajaran guru memberikan kesimpulan terhadap materi dan membacakan kembali surat at-Takwir secara klasikal.

Kedua, pada teknik bermain dipandang sebagai suatu aktivitas yang paling menyenangkan karena seluruh anggota tubuh terlibat untuk menyelami konsep dengan tanpa ada paksaan dan tekanan. Sehingga kegiatan pembelajaran lebih bermakna, beberapa nilai yang dapat diambil dari kegiatan bermain, diantaranya: a) Nilai fisik: Bermain adalah suatu aktifitas yang terpenting dalam perkembangan fisik motorik anak; b) Nilai pendidikan: Melalui bermain anak akan mendapatkan banyak pengetahuan, melalui alat-alat permainan ataupun metode permainan yang beragama diantaranya, bentuk sebuah benda, warna, dan huruf hijaiyah; c) Nilai sosial: Dengan bermain akan menumbuhkan jiwa sosial, empati dengan teman-temannya; d) Nilai akhlak: Bermain akan mengajarkan anak tentang mana yang baik dan tidak, mana yang boleh dan tidak, mereka akan mengenal tentang akhlak setiap orang, misalnya: adil, jujur, amanat, kepercayaan diri dan jiwa sportif; e) Nilai kreatifitas: Media permainan merupakan wahana yang tepat dalam pengembangan karakter anak yaitu rasa ingin tahu yang tinggi (curiosity) yang dapat menstimulasi daya kreatifitas anak kedepannnya; f) Nilai pribadi: Melalui bemain anak akan dapat mengetahui potensi diri, seperti mengetahui kemampuan dan keterampilan. Bermain pula sebagai arahan anak untuk mengembangkan kepercayaan dirinya melalui belajar memecahkan masalah; g) Nilai pengobatan: Dari Bermain sang anak dapat melepaskan diri dari 
keterkungkungan, sehingga seringkali kita menjumpai anak yang di rumah penuh dengan peraturan, perintah dan larangan, akan terlihat banyak bermain di luar rumah daripada di dalam rumah. Bermain merupakan terapi bagi diri anak sendiri didalam menghilangkan rasa rendah diri. Mereka akan merasakan adanya penerimaan dari pihak luar (teman bermain) karena adanya penghargaan yang sama bagi dirinya (Mursi, 2003).

Adapun tahapan mengenalkan huruf hijaiyah pada teknik MATA salah satunya dengan metode jari Qur`an, terdapat relevansi yang berfungsi untuk mengikat konsep pengetahuan huruf hijaiyah dengan bermain sebagai upaya mengasah kemampuan motorik anak dan mudah untuk dihafal karena diiringi dengan konsep bernyanyi, sehingga pengetahuan anak bertambah luas. Adapun langkah dalam metode jari Qur`an dapat disajikan dalam langkah berikut ini: (1) Ulangi secara terus menerus gerakan jari sambil mengucapkan huruf hijaiyah sesuai dengan pembagian huruf di tangan kanan dan kiri; (2) Perkuat pemahaman anak dengan huruf-huruf di tangan kanan terlebih dahulu baru huruf-huruf di tangan kiri; (3) Buatlah anak memahami gerakan jari dan huruf hijaiyahnya dengan berbagai macam permainan dan lagu sehingga menyenangkan; (4) Kalau anak sudah hafal posisi masing-masing huruf hijaiyah di tangan kanan dan kiri, buatlah permainan acak jari. Jadi gerakan jari secara acak kanan dan kiri, biarkan anak menjawab dengan benar; (5) Tulislah tiap-tiap huruf di atas kertas ukuran $2 \times 5 \mathrm{~cm}$, biarkan anak mengambil kartu huruf hijaiyah sesuai dengan gerakan jari yang diminta; (6) Berilah pujian setiap anak berhasil dengan tepuk "anak hebat". Atau siapkan toples "anak hebat" buatlah bintang warna-warni dengan kertas. Berilah anak sebuah bintang apabila anak berhasil menjawab pertanyaan yang diajukan oleh Anda. Kemudian di akhir bulan anak-anak bisa menukarkan bintang tersebut dengan hadiah yang sudah anda siapkan terlebih dahulu; (7) Setelah anak-anak dirasakan menikmati belajar huruf hijaiyah dengan permainan. Tahap berikutnya anak-anak mulai dilatih motorik halusnya untuk menulis huruf hijaiyah, dimulai dengan menulis bentuk dasarnya dahulu (Wulandari, 2011).

Berikut disajikan cara mengenal huruf hijaiyah dengan media jari tangan, ada tiga hal yang dilakukan didalam pengembangan metode jari Qur'an yaitu dengan dongeng, permainan, dan hadiah. Maka di metode jari Qur`an ini penyampaian dengan ketiga pendekatan diatas ditambah dengan gerak dan lagu.

Tabel 2. Metode Jari Qur`an

(Wulandari, 2011)

\begin{tabular}{|c|c|c|c|}
\hline Kanan & $\begin{array}{c}\text { Huruf } \\
\text { Hijaiyah }\end{array}$ & $\begin{array}{c}\text { Huruf } \\
\text { Hijaiyah }\end{array}$ & Kiri \\
\hline & 1 & $\varepsilon$ & 30 \\
\hline & ه , م & ك, ك & 20 \\
\hline & ق & س & \\
\hline & $\begin{array}{c}j, j, j \\
j\end{array}$ & ظ, ضر ضر & \\
\hline Sil & 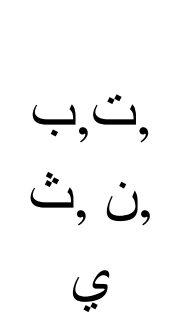 & $\begin{array}{l}\dot{\tau}, \tau, \\
\tau, \varepsilon, \dot{\varepsilon}\end{array}$ & $1 \frac{2}{5}$ \\
\hline
\end{tabular}


Ketiga bercerita, Melalui teknik mata, cerita mengandung makna membelajarkan anak baca tulis al-Qur`an melalui cerita. Artinya bercerita mengandung pengertian bahwa bagi anak, menyimak cerita merupakan suatu bentuk pengalaman (1) pengalaman menyimak pesan, informasi dalam dialog antar tokoh, (2) pengalaman mengamati gerak dan perilaku tokoh melalui cerita, (3) pengalaman mencerna dan merefleksikan apa yang telah disimak dan diamati dalam cerita (Musfiroh, 2005).

Dalam bercerita pada teknik MATA ada beberapa tahapan yang perlu disiapkan dan diikuti oleh para pendidik, diantaranya: Pertama, mempersiapkan cerita yang akan disampaikan. Kedua, menyiapkan media, untuk media dibuat dari bahan yang murah ataupun memanfaatkan barang bekas sehingga dapat menggali kreatifitas anak, utamanya media dapat menjadikan cerita menarik dan bermakna bagi anak. Ketiga, mengekspresikan karakter tokoh, baik dengan suara maupun dengan mimik (body language). Keempat, selalu sisipkan kegiatan menulis dan membaca huruf hijaiyah ataupun kata dalam bahasa Arab yang berkaitan dengan cerita yang disampaikan, hal ini bertujuan untuk meningkatkan kemampuan baca tulis alQur`an anak. dan untuk kelas 4-6 bisa pula disiapkan ayat-ayat tertentu yang berkaitan dengan cerita, jadi di tengah bercerita mintalah anak untuk membacakan ayatnya dengan benar. Kelima, evaluasi, pada tahapan ini guru menyiapkan lembar observasi yang berisikan kemampuan yang diharapkan guru dari siswa berdasarkan indikator capaian pada kegiatan bercerita dengan teknik MATA. Bentuk observasinya dapat dalam bentuk ceklist untuk kolom isian tabel, bentuk narasi ataupun menggunakan keduanya.
Salah satu contoh narasi dalam bentuk dongeng pada teknik bercerita untuk kelas bawah adalah sebagai berikut:

Tabel 3. Teknik Bercerita untuk Kelas Bawah

\begin{tabular}{|c|c|}
\hline Judul & Raja Abrahah \\
\hline Jenjang & $\begin{array}{l}\text { Kelas 1-3 Diniyyah } \\
\text { Takmiliyyah }\end{array}$ \\
\hline Materi & $\begin{array}{l}\text { Surat al-Fil dan kosakata } \\
\text { bahasa Arab (gajah, burung, } \\
\text { raja Abrahah, Ababil) }\end{array}$ \\
\hline $\begin{array}{l}\text { Pokok } \\
\text { cerita }\end{array}$ & $\begin{array}{l}\text { Bermula dari Abrahah } \\
\text { al-Habsy yang melihat bangsa } \\
\text { Arab berbondong-bondong ke } \\
\text { Mekah untuk menunaikan } \\
\text { ibadah haji. Lalu Abrahah } \\
\text { membangun gereja yang besar } \\
\text { di Shan'a. } \\
\text { Dia bermaksud untuk } \\
\text { mengalihkan perhatian bangsa } \\
\text { Arab, yang tadinya pergi ke } \\
\text { Mekkah jadi pergi ke Shan'a } \\
\text { gereja, tetapi rencananya } \\
\text { gagal. Akhirnya raja Abarahah } \\
\text { marah dan menghimpun } \\
\text { pasukan sejumlah enam puluh } \\
\text { ribu orang dan sembilan ekor } \\
\text { gajah yang tangguh. } \\
\text { Kala itu Abrahah } \\
\text { menunggangi gajah yang } \\
\text { paling besar dan paling kuat. } \\
\text { Pasukan itu hendak menyerang } \\
\text { dan menghancurkan Ka'bah, } \\
\text { namun ditengah perjalanan } \\
\text { gajah-gajah yang ditunggangi } \\
\text { tak mau melanjutkan } \\
\text { perjalanan, mereka tak mau } \\
\text { diarahkan menuju Ka'bah. } \\
\text { Mereka malah bertolak } \\
\text { melawan arah. Saat itulah Allah } \\
\text { mengirimkan serombongan } \\
\text { burung Ababil } \\
\text { melempari pasukan Abrahah } \\
\text { dengan batu yang berasal dari }\end{array}$ \\
\hline
\end{tabular}




\begin{tabular}{|l|l|}
\hline tanah yang dibakar. Setiap \\
burung membawa tiga butir \\
batu dan melemparkannya \\
pada pasukan yang dipimpin \\
Abrahah itu. Batu-batu yang \\
dilemparkan burung-burung \\
Ababil menjadikan pasukan \\
gajah mati bagai daun-daun \\
yang dimakan ulat. Tubuh \\
mereka hancur lebur tak \\
berwujud lagi. Itulah kuasa \\
Allah 'azza wajalla. \\
\hline
\end{tabular}

Kemudian contoh narasi dalam bentuk dongeng pada teknik bercerita untuk kelas atas adalah sebagai berikut:

Tabel 4. Teknik Bercerita untuk Kelas Bawah

\begin{tabular}{|l|l|}
\hline Strategi & Melibatkan Anak \\
\hline Judul & Asal Muasal Terjadinya Awan \\
\hline Jenjang & $\begin{array}{l}\text { Kelas } 4 \text {-6 } \\
\text { Takmiliyyahah }\end{array}$ \\
\hline Materi & Surat Ad-Dzariyat: 2 \\
\hline Media & $\begin{array}{l}\text { Media kertas, buku gambar, } \\
\text { suara yang bervariasi, } \\
\text { kartun/cerita pendek } \\
\text { bergambar }\end{array}$ \\
\hline $\begin{array}{l}\text { Pokok } \\
\text { cerita }\end{array}$ & $\begin{array}{l}\text { dariang berolahraga, Zahra duduk } \\
\text { santai di serambi depan } \\
\text { rumahnya. Saat liburan seperti } \\
\text { ini biasanya } \\
\text { menghabiskan } \text { Zahra } \\
\text { membaca buku. Dia memang } \\
\text { gemar membaca, rasa ingin } \\
\text { tahunya yang tinggi memicu ia } \\
\text { untuk terus semangat mencarai } \\
\text { ilmu lewat buku. } \\
\text { langit. Mesekali Zahra melihat } \\
\text { dalam hati. Langit memang } \\
\text { terlihat gelap. Sinar matahari } \\
\text { tak lagi panas menyengat. } \\
\text { Perlahan sinarnya mulai } \\
\text { tertutup awan. }\end{array}$ \\
\hline
\end{tabular}

bentuknya beda-beda"
ucapnya dalam hati. "ada yang
mirip orang sujud, menyerupai
ikan. Nah kalau yang ujung
sana mirip apa? Tanya bunda
yang tiba-tiba telah berdiri di
belakang Zahra. Seperti
membentuk tulisan Allah bun.
Subhanallah cantik sekali ya,
semua ciptaan Alloh memang
luar biasa, disanalah tersimpan
bukti-bukti kekuasaan Allah."
Sahut bunda.

Kemudian

zahra bertanya, bunda sebenarnya awan itu dari mana? Awan adalah sekumpulan tetesan air atau kristal es di dalam atmosfer. Kemudian setelah melalui titik jenuh, terjadilah pengembunan atau pemadatan uap air di dalam udara. Makanya terlihat menggumpal, "Kata Bunda. Lihatlah di al-Qur'an surat $a d$ Dzariyat, ayat 2 (anak-anak diminta untuk membacakan ayat tersebut).

Apakah awan-awan itu semuanya berwarna putih bunda?" tanya Zahra. Ooh tidak sebenarnya awan mempunyai banyak sekali warna, ada yang merah, jingga, kuning, hijau, biru, nila dan unggu. Nah saat warnawarna itu bergabung menjadi satu, maka warna yang muncul adalah warna putih." Ooh gitu ya bun, tapi kenapa ada awan yang berwarna keabu-abuan? Semakin tebal awan semakin sedikit cahaya yang diteruskan akibatnya awan berwarna ke abu-abuan..... 
78 | Upaya Meningkatkan Keterampilan Mengajar Baca Tulis Al-Qur`An bagi Guru

\begin{tabular}{|l|l|}
\hline \multicolumn{1}{|c}{ Kisah ini bisa } \\
dilanjutkan dengan jenis awan \\
dan awan yang datang dan \\
menjadi tanda adzab bagi \\
kaum ' $A d$.
\end{tabular}

Selanjutnya untuk mengetahui tingkat efektivitas teknik Menyimak Bermain dan Bercerita menggunakan beberapa tahapan pengujian, diantaranya yaitu:

\section{Uji Normalitas}

Hasil Uji Normalitas menggunakan Uji Shairo-Wilk

Tabel 5. Hasil Uji Normalitas Menggunakan Uji Shairo-Wilk

\begin{tabular}{|c|c|c|c|c|c|c|}
\hline \multicolumn{7}{|c|}{ Test of Normality } \\
\hline & \multicolumn{3}{|c|}{ Kolmogorov-Smirnov $^{\mathrm{a}}$} & \multicolumn{3}{|c|}{ Shapiro-Wilk } \\
\hline & Statistic & df & Sig. & Statistic & $\mathrm{Df}$ & Sig. \\
\hline Pretest & .107 & 50 & $.200^{\circ}$ & .981 & 50 & .579 \\
\hline Posttest & .130 & 50 & .034 & .970 & 50 & .241 \\
\hline
\end{tabular}

Dasar pengambilan keputusan dalam uji normalitas Shapiro-Wilk

Jika Sig. > 0,05, maka distribusi normal Jika Sig. $<0,05$, maka distribusi tidak normal.

Hasil pada uji distribusi data pre test, sebaran data menujukkan data sig. 0,579> 0,05, artinya data terdistribusi normal. Adapun hasil pada uji distribusi post test, sebaran data menunjukkan sig. $0.241>$ 0,05 , yang mana hasil sebaran datanya terdistribusi normal.

\section{Uji Berpasangan}

Setelah data dapat dibuktikan terdistribusi normal, maka pengujian efektifitas tentang Workshop terhadap peningkatan pemahaman peserta dapat dilakukan dengan Uji $\mathrm{T}$ Berpasangan. Adapun hasilnya berikut dibawah ini:

Tabel 6. Hasil Uji T Berpasangan

Paired Samples Test

\begin{tabular}{|c|c|c|c|c|c|c|c|c|}
\hline & \multicolumn{5}{|c|}{ Paired Differences } & $\mathrm{t}$ & df & $\begin{array}{l}\text { Sig. (2- } \\
\text { tailed) }\end{array}$ \\
\hline & \multirow{2}{*}{$\begin{array}{l}\mathrm{Me} \\
\text { an }\end{array}$} & \multirow{2}{*}{$\begin{array}{c}\text { Std. } \\
\text { Dev } \\
\text { iatio } \\
n\end{array}$} & \multirow{2}{*}{$\begin{array}{l}\text { Std. } \\
\text { Erro } \\
\mathrm{r} \\
\text { Mea } \\
\mathrm{n}\end{array}$} & \multicolumn{2}{|c|}{$\begin{array}{c}95 \% \\
\text { Confidence } \\
\text { Interval of the } \\
\text { Difference }\end{array}$} & & & \\
\hline & & & & Lower & Upper & & & \\
\hline $\begin{array}{ll}\text { Pair } & \text { Pretest - } \\
1 & \text { Posttest }\end{array}$ & $\begin{array}{r}- \\
8.8 \\
800 \\
0\end{array}$ & $\begin{array}{r}2.49 \\
604\end{array}$ & $\begin{array}{r}.352 \\
99\end{array}$ & $\begin{array}{r}- \\
9.589 \\
37\end{array}$ & $\begin{array}{r}- \\
8.170 \\
63\end{array}$ & $\begin{array}{r}25.1 \\
56\end{array}$ & 49 & .000 \\
\hline
\end{tabular}

Dasar pengambilan keputusan dalam Uji T Paired

Jika Sig. < 0,05, maka terdapat perbedaan Jika Sig. > 0,05, maka tidak terdapat perbedaan

Hasil menunjukkan, diketahui hasil Sig. (2 Tailed) sebesar $0,001<0,05$ hasilnya lebih kecil, maka dapat disimpulkan bahwa dengan adanya pelatihan teknik MATA terdapat perbedaan sebelum dan sesudah atau dapat disimpulkan pelatihan ini mampu meningkatkan pemahaman guru Madrasah Diniyyah Takmiliyah.

Hasil efektifitas pada pelatihan teknik MATA, untuk mengetahuinya dilakukan uji pre test dan post test. Butir soal yang diberikan sejumlah 30 soal yang berkaitan dengan tiga aspek yakni, materi menyimak, bermain dan bercerita. Hasil analisis deskriptif peningkatan disajikan pada tabel berikut ini.

Tabel 7. Statistik Deskriptif Tentang Hasil Pre Test Dan Post Test

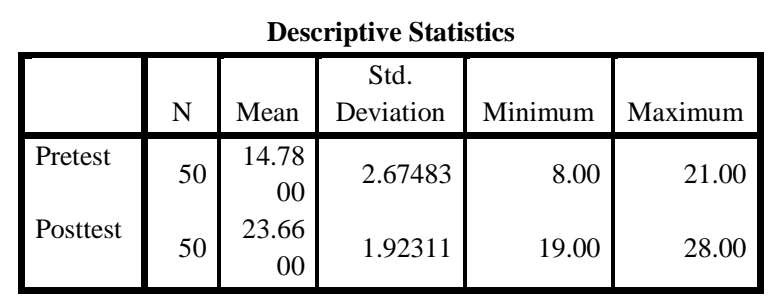

Hasil menunjukkan pada saat uji pre test presentase pemahaman peserta pelatihan rata-rata berada pada poin 14,7 , hasil tersebut merupakan data dari 50 
orang peserta. Setelah dilakukan pelatihan teknik MATA maka di akhir sesi kegiatan dilaksanakan uji post test dengan soal yang sama, hasil menunjukkan rata-rata peningkatan pemahaman peserta pelatihan meningkat menjadi 23,3 pada poin maksimal 30. Secara presentase peningkatan pemahaman pada pre test kemampuan awal berada pada angka $49 \%$ dan setelah dilakukan pelatihan meningkat menjadi 78,9\%. Dapat disimpulkan bahwa pelatihan teknik MATA mampu meningkatkan pemahaman guru Madrasah Diniyyah Takmiliyyah sejumlah 8.6 point atau sejumlah $29,9 \%$.

Hasil diatas menunjukkan guru MDT di Kecamatan Pangalengan sudah mendapatkan tambahan pengetahuan khususnya dalam metode pembelajaran baca tulis al-Qur`an pada siswa. Hasil ini sesuai dengan hasil wawancara dengan angket, disebutkan bahwasannya guru-guru MDT di Kecamatan Pangalengan belum pernah mendapatkan pelatihan jenis apapun, terutama pelatihan dalam pendekatan dan metode pembelajaran.

Teknik menyimak yang telah dipahami oleh guru dengan baik tatkala dipraktekkan dalam kegiatan pembelajaran akan memberikan kesempatan kepada anak untuk mengikuti instruksi tugas yang diberikan guru, bertanya apabila kurang dipahami materinya, dan menumbuhkan sikap ingin tahu (curiosty) lebih dalam (Imam, 2014). Pada teknik bermain, mengembangkan kreativitas, maka berarti kreativitas itu bisa tampil dini dalam kehidupan anak dan terlihat pada saat ia bermain, karena ketika bermain anak berimajinasi dan mengeluarkan ide-ide yang tersimpan di dalam dirinya. Anak mengekspresikan pengetahuan yang dia miliki tentang dunia dan kemudian juga sekaligus bisa mendapatkan pengetahuan baru, dan semua dilakukan dengan cara menggembirakan hatinya (Amiran, 2016).
Sedangkan pada teknik bercerita juga dapat melatih daya serap atau daya tangkap anak, melatih daya pikir anak, melatih daya kosentrasi untuk mengambil hikmah dari materi yang telah disampaikan (Arinoviani, Pudjawan, \& Antara, 2016)

Implementasi dari pelatihan teknik MATA bagi guru setelah meningkatnya pemahaman mereka terhadap materi baca tulis al-Qur`an adalah dengan memperhatikan tiga aspek. Pertama, isi adalah input (peserta didik) sebagai objek dalam pendidikan, kedua, proses/transformasi merupakan mesin yang akan mencetak anak didik sesuai yang diharapkan, dan tujuan merupakan hasil akhir yang hendak dicapai atau output. Perlu ditegaskan bahwa proses/transformasi dalam kerjanya dipengaruhi beragam faktor, seperti fasilitas, waktu, lingkungan, sumber daya, dan pendidik, dimana faktor tersebut menjadi penentu output (Munirah, 2015).

Dengan demikian, jelas terdapat korelasi yang signifikan antara input yang didapatkan oleh seorang pendidik dengan output yang akan diperoleh. Seorang pendidik hendaknya menambah kapasitas dirinya dalam hal cara mengajar yang relevan sesuai usia perkembangan anak, mampu mengelola pembelajaran dengan sebaik-baiknya, melibatkan seluruh perangkat pendidikan agar tercapai tujuan sesuai yang dicita-citakan, khususnya dalam hal ini pembelajaran baca tulis alQur`an.

\section{KESIMPULAN}

Permasalahan di lapangan tentang kesulitan guru Madrasah Diniyyah Takmiliyyah di Kecamatan Pangalengan dalam mencari inovasi pembelajaran materi Baca Tulis al-Qur`an dapat ditingkatkan melalui teknik Menyimak, Bermain dan Bercerita (MATA). Hasil menujukkan peningkatan pemahaman guru 
pada teknik MATA meningkat rata-rata sampai pada $78,9 \%$, meningkat sejumlah $23,3 \%$ dari kemampuan awal rata-rata berada pada $49 \%$. Adapun penerapan teknik MATA memiliki beberapa kendala, misalnya guru sulit mengkondisikan anak untuk tetap fokus, mencari strategi agar anak tetap semangat dan antusias dalam mengikuti pelajaran, dan penguasaan dan penerapan teknik MATA masih belum maksimal. Sedangkan dampak positif penerapan teknik MATA ini meningkatkan keaktifan dan kreatifitas guru dan mampu melibatkan seluruh siswa dalam pembelajaran.

\section{UCAPAN TERIMA KASIH}

Penulis haturkan ucapan terimakasih kepada pengelola Jurnal Obsesi Universitas Pahlawan Tuanku Tambusai, Dinar Nur Inten, M.Pd. dan Arif Hakim, M.Pd. selaku tim penulis, dan civitas akademika Fakultas Tarbiyah dan Keguruan Universitas Islam Bandung. Semoga Karya Tulis ini bermanfaat untuk sesama.

\section{DAFTAR PUSTAKA}

Adhim, M. (2013). Segenggam Iman untuk Anak Kita. Yogyakarta: Pro-U Media.

Amiran, S. (2016). Efektifitas Penggunaan Metode Bermain di PAUD Nazareth Oesapa. Jurnal Pendidikan Anak, 5(1), 710-716. Retrieved from https://journal.uny.ac.id/index.php/jp a/article/view/12367

Arinoviani, K.D., Pudjawan, K., \& Antara, P. . (2016). Penerapan Metode Bercerita untuk Meningkatkan Kemampuan Berbahasa Inggris Anak Kelompok A1 dalam Kegiatan Ekstrakulikuler. Jurnal Pendidikan Guru Pendidikan Anak Usia Dini, 4(2), 1-10. Retrieved from https://ejournal.undiksha.ac.id/index. php/JJPAUD/article/viewFile/7751/5
290

Cahyaningrum, E. S., Sudaryanti, \& Nurtanio, A. P. (2017). Pengembangan Nilai-Nilai Karakter Anak Usia Dini Melalui Pembiasaan dan Keteladanan. Jurnal Pendidikan Anak, 6(2), 203-213.

Chambers, R. (1996). PRA (Participatory Rural Appraisal) Memahami Desa Secara Partisipatif. Yogyakarta: Kanisuis.

Dhieni, N., et. al. (2008). Metode Pengembangan Bahasa. Jakarta: Universitas Terbuka.

Hadi, S. (2017). Story-telling: Upaya Meningkatkan Daya Simak dalam Keterampilan Menyimak Interaktif Berbahasa. Brilliant: Jurnal Riset Dan Konseptual, 2(2), 163-177. Retrieved from https://jurnal.unublitar.ac.id/index.ph $\mathrm{p} /$ briliant/article/view/42/pdf

Imam. (2014). Meningkatkan Kemampuan Menyimak Siswa Kelas 1 Melalui Teknik Permainan Pesan Berantai Pada Pembelajaran Bahasa Indonesia. Jurnal Pedagogia, 3(2), 111-118. Retrieved from https://www.researchgate.net/publica tion/309470945_Meningkatkan_Ke mampuan_Menyimak_Siswa_Kelas_ I_Melalui_Teknik_Permainan_Pesan _Berantai_Pada_Pembalajaran_Baha sa_Indonesia

Kurniawan, H., Khomsiyatun, U., \& Samiaji, M. H. (2018). Literasi Parenting. Jakarta: Gramedia.

Madyawati, L. (2016). Strategi Pengembangan Bahasa pada Anak. Jakarta: Prenadamedia Group.

Muhadi, Y. (2016). Sudah Benarkah Cara Kita Mendidik Anak. Yogyakarta: Diva Press.

Munirah. (2015). Sistem Pendidikan Indonesia: Antara Keinginan dan Realita. Jurnal Auladuna, 2(2), 233245. Retrieved from http://journal.uinalauddin.ac.id/index.php/auladuna/ar 
ticle/view/879

Mursi, M. (2003). Seni Mendidik Anak terj. Tarbiyatul Aulad Fil Islam. Jakarta: Pustaka Al-Kautsar.

Musfiroh. T. (2005). Cerita Untuk Perkembangan Anak. Yogyakarta: Navila Idea.

Musthafa, F. (2004). Manhaj Pendidikan Anak Muslim (terjemahan dari: Manhajuth-Thiflil Muslim; Dalilul Mua'alimin Wal Aba'allat-Tarbiyati Abna' Fi Riyadhil Athfal Wal Madrasatil Ibtidaiyah). Jakarta: Mustaqim.

Rusman. (2013). Model-Model Pembelajaran. Jakarta: Rajawali Press.

Wulandari, S. (2011). Jari-jari Qur'an: Metode Cepat Lancar Menulis dan Membaca Al-Qur'an dengan Jari Tangan. Jakarta: PT. Kawan Pustaka. 